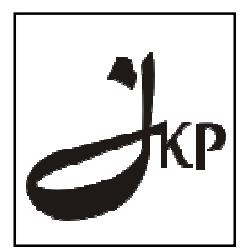

Jurnal Konseling dan Pendidikan

ISSN Cetak: 2337-6740 - ISSN Online: 2337-6880

http://jurnal.konselingindonesia.com

Volume 1 Nomor 1, Februari 2013, HIm 15-21

\title{
Konseling Online Sebagai Salah Satu Bentuk Pelayanan E-konseling
}

\author{
Ifdil $^{1^{*}}$ Zadrian $\mathrm{Ardi}^{1}$
}

${ }^{I}$ Fakultas Ilmu Pendidikan, Universitas Negeri Padang

\begin{abstract}
The development of technology has changed the lives of the world as well as counseling. Counseling is not only face to face (FTF) in a confined space, but it can be done through distance format in assistive technology that online counseling. Counseling is an integral part of e-counseling services. Various applications have been developed to support the implementation of counseling in Indonesia, as well as with use of other technologies that can support the implementation of guidance and counseling services. E-counseling services in general and in particular online counseling are an alternative attempt to do by counselors in an effort to prevent, reduce and eliminate the problem. Counselors should have a mastery of the technology and has a minimum competency in the administration of e-counseling services, at least insights about e-counseling services. This article will present a variety of things with regard to e-counseling service specifically about online counseling
\end{abstract}

Keyword:Konseling Online, e-konseling, konseling, face to face (FtF), teknologi.

Copyright (C) 2013 IICE - Multikarya Kons - All Rights Reserved Indonesian Institute for Counseling and Education (IICE) Multikarya Kons

\section{LATAR BELAKANG}

Hadirnya teknologi informasi dan komunikasi membuka era baru dalam profesi konseling (Zeng, 2010). Kondisi ini merupakan tantangan tersendiri bagi para guru bimbingan dan konseling (BK)/konselor untuk dapat berperan serta dan dapat menguasai berbagai keterampilan didalamnya. Sering kali permasalahan-permasalahan yang dihadapi siswa/remaja berawal dari dunia online, (Csiernik, 2006) menyatakan bahwa teknologi informasi juga dapat secara sosial mengisolasi dan telah menyebabkan masalah sosial baru khususnya di kalang anak-anak dan remaja. Tidak hanya itu, konselor juga dapat mengalami masalah di lapangan berawal dari dunia online. Lebih lanjut dunia online dapat dijadikan sarana dalam membantu guru bk/konselor untuk meng-update pengetahuannya guna membantu menjalankan tugas, sepeti mencari referensi, diskusi dan sebagainya. Seiring

*Telp dan/atau Alamat Email Koresponden :

${ }^{1}$ Email: ifdil@konselor.org 
dengan itu penyelenggaraan konseling juga tidak hanya dilakukan secara face to face (Ft $F$ ) dalam satu ruang tertutup, namun bisa dilakukan melalui format jarak jauh yang di bantu teknologi yang selanjutnya dikenal dengan istilah e-konseling (Gibson: 2008). Istilah e-konseling berasal dari bahasa Inggris yaitu e-counseling (electronic counseling) yang secara singkat dapat diartikan yaitu proses penyenggaraan konseling secara elektronik. Cikal bakal berdirinya istilah e-counseling berawal dari penyelenggaraan konseling online pada dekade 1960-1970, sebagaimana Koutsonika (2009) menyebutkan bahwa konseling online pertama kali muncul pada dekade 1960 dan 1970 dengan perangkat lunak program Eliza dan Parry.

Di Indonesia sendiri tidak ada informasi pasti tentang kapan awalnya muncul istilah e-konseling, meskipun sebelumnya istilah ini ada yang menyebutnya dengan istilah cyber konseling, virtual konseling dan sebagainya. Namun secara khusus Ifdil (2009) memperkenalkan istilah Pelayanan E-Konseling di Indonesia. Istilah ini merangkaikan kata pelayanan dan kata e-konseling. Pelayanan e-konseling tidak hanya terbatas pada penyelenggaraan konseling (istilah yang paling populer untuk mengebut konseling individual) saja, namun diperluas menjadi penyenggaraan BK secara keseluruhan dengan bantuan teknologi. Tidak hanya online konseling melalui internet namun juga semua aspek pemanfaatan teknologi informasi dan komunikasi lainnya dalam penyenggaraan BK. Seperti penggunaan dan pemanfaatan program pengolahan instrumentasi, himpunan data siswa, aplikasi manajemen konseling, pemanfaatan media saat pemberian layanan klasikal di kelas dan sebagainya termasuk juga pemanfaatan telepon untuk penyelenggaraan konseling.

Ifdil (2009) Sejak lahirnya istilah Pelayanan e-konseling dan sebelumnya telah banyak dikembangkan berbagai aplikasi penunjang penyelenggaraan BK di Indonesia seperti Program Aplikasi untuk pengolahan Alat Ungkap Masalah (AUM), Program Analisis Tugas Perkembangan (ATP), Program Daftar Cek Masalah (DCM), Program Aplikasi IKMS, Program Database Siswa, Program E-sosiometri, Sistem Informasi Managemen Bimbingan dan Konseling (SIMBK) dan sebagainya termasuk lahirnya berbagai situs-situs penyedia layanan konseling online.

Situs-situs Konseling Online secara khusus memanfaatkan berbagai media online lainnya yang bisa digunakan untuk penyelenggaraan konseling online seperti jejaring sosial misalnya facebook, twitter, myspace; email; dan beberapa program aplikasi untuk chatting (instant messaging) seperti skype, messenger, google talk, window livemessenger; bahkan penggunaan telepon dan handphone serta media khusus teleconference lainnya.

Pelayanan ini dilakukan konselor dalam upaya membantu mengentaskan dan menangani permasalahan klien. Gibson (2008) menyebutkan pelayanan ini dilakukan oleh konselor untuk memberikan kenyamanan bantuan yang dibutuhkan konseli ketika menghadapi suatu masalah dan tidak mungkin dilakukan secara face to face(Gibson: 2008).

Beberapa tahun kedepan kebutuhan akan pelayanan konseling secara online akan meningkat (Mallen: 2005). Konseling online akan menjadi alternatif dalam penyelenggaraan konseling. Kondisi tersebut mau tidak mau, mengharuskan para guru bk/konselor untuk menguasai keterampilan pelayanan e-konseling secara umum dan konseling online secara khusus. Jika tidak kondisi BK kita akan kian terpuruk, guru BK/konselor dipandang gagap teknologi, terlalu rigit dan tidak mau berkembang. Beberapa temuan di lapangan memperlihatkan kondisi yang sangat memprihatinkan. Masih ada guru BK/konselor yang belum mengenal internet, tidak memiliki alamat email, tidak memanfaatkan fasitas teknologi informasi yang disediakan sekolah, bahkan masih ada guru bk/konselor yang belum bisa menggunakan komputer sama sekali untuk keperluan yang sederhana, dalam menunjang penyelenggaraan tugasnya.

Untuk menjawab permasalahan tersebut artikel ini lebih lanjut akan menyajikan dan mendiskripsikan salah satu bentuk Pelayanan e-konseling yaitu penyelenggaraan konseling secara online, diharapkan artikel ini dapat memberi pengetahuan dan wawasan kepada guru bk/konselor yang nantinya dapat diaplikasikan untuk menjalankan tugasnya dalam mengentaskan permasalahan yang dihadapi oleh konseli/klien.

\section{KONSELING ONLINE}

Koutsonika (2009) menyebutkan bahwa konseling online pertama kali muncul pada dekade 1960 dan 1970 dengan perangkat lunak program Eliza dan Parry, padaperkembangan awalkonseling online dilakukan berbasis 
teks, dan sekarang sekitarsepertiga dari situs menawarkan konseling hanya melalui e-mail (Shaw \& Shaw dalam Koutsonika, 2009). Karena kemajuan teknologi metode lain juga digunakan seperti livechat, konseling telepon dan konseling video.

Istilah konseling online merupakan dua kata yaitu kata "konseling" berasal dari kata "Counseling" (Inggris) dan kata "online". Kata konseling mengacu kepada individual konseling (konseling perorangan) yaitu proses pemberian bantuan yang dilakukan melalui wawancara konseling oleh seorang ahli (disebut konselor) kepada individu yang sedang mengalami sesuatu masalah (disebut klien) yang bermuara pada teratasinya masalah yang dihadapi klien". (Prayitno dan Erman Amti, 2004).

Sedangkan kata online diartikan adalah sebagai komputer atau perangkat yang terhubung ke jaringan (seperti Internet) dan siap untuk digunakan (atau digunakan oleh) komputer atau perangkat lain. (Business Dictionary, 2011). Lebih lanjut dalam Wikipedia, online adalah dimaknai dalam jaringan atau daring atau keadaan saat sesuatu terhubung ke dalam suatu jaringan atau sistem (umumya internet atau ethernet). Jadi istilah konseling online dapat dimaknai secara sederhana yaitu proses konseling yang dilakukan dengan alat bantu jaringan sebagai penghubung antara konselor dengan kliennya. Hal ini senada dengan yang dikemukakan oleh (Amani, 2007) Konseling Online adalah konseling melalui internet yang secara umum merujuk pada profesi yang berkaitan dengan layanan kesehatan mental melalui teknologi komunikasi internet. Lebih lanjut Fields (2011) menyebutkan bahwa konseling online adalah layanan terapi yang relatif baru. Konseling dikembangkan dengan menggunakan teknologi komunikasi dari yang paling sederhana menggunakan email, sesi dengan chat, sesi dengan telp pc-to-pc sampai penggunaan dengan penggunaan webcam (video live sessions), yang secara jelas menggunakan komputer dan internet. Haberstroh (2011) menjelaskan bahwa konseling online adalah klien dan konselor berkomunikasi dengan menggunakan streaming video dan audio. Capill (tt). Konseling menggunakan koputer sehingga tercipta komunisi antara klien dengan Konselor.

Dari beberapa pendapat di atas dapat dipahami dan disimpulkan bahwa konseling online adalah usaha membantu (therapeutic) terhadap klien/konseli dilakukan dengan memanfaatkan teknologi informasi, komputer dan internet.

\section{PROSES KONSELING ONLINE}

Proses konseling online bukanlah sebuah proses yang sederhana. Diperlukan kemampuan pendukung lain selain ketrampilan dasar konseling, sebagaimana yang dikemukan oleh Koutsonika (2009) : Konseling online bukanlah merupakan sebuah proses yang simple. Sebaliknya sebuah proses yang kompleks dengan sejumlah isu yang berbeda dan menantang yang memiliki karakteristik tersendiri. Kemudian berkenaan dengan etika, masalah penggunaan teknologi, latar belakang pendidikan dan keterampilan, masalah hukum, bisnis dan masalah manajemen.

Selain apa yang dikemukan di atas, secara spesifik penyedia konseling online secara rinci biasanya memberikan tata cara dalam melakukan proses konseling online. Namun pada pembahasan artikel ini penulis memberikan gambaran umum proses konseling online. 
Ifdil (2011) menyebutkan bahwa proses konseling dapat dibagi menjadi tiga tahap seperti yang terdapat pada gambar 1 di bawah ini :

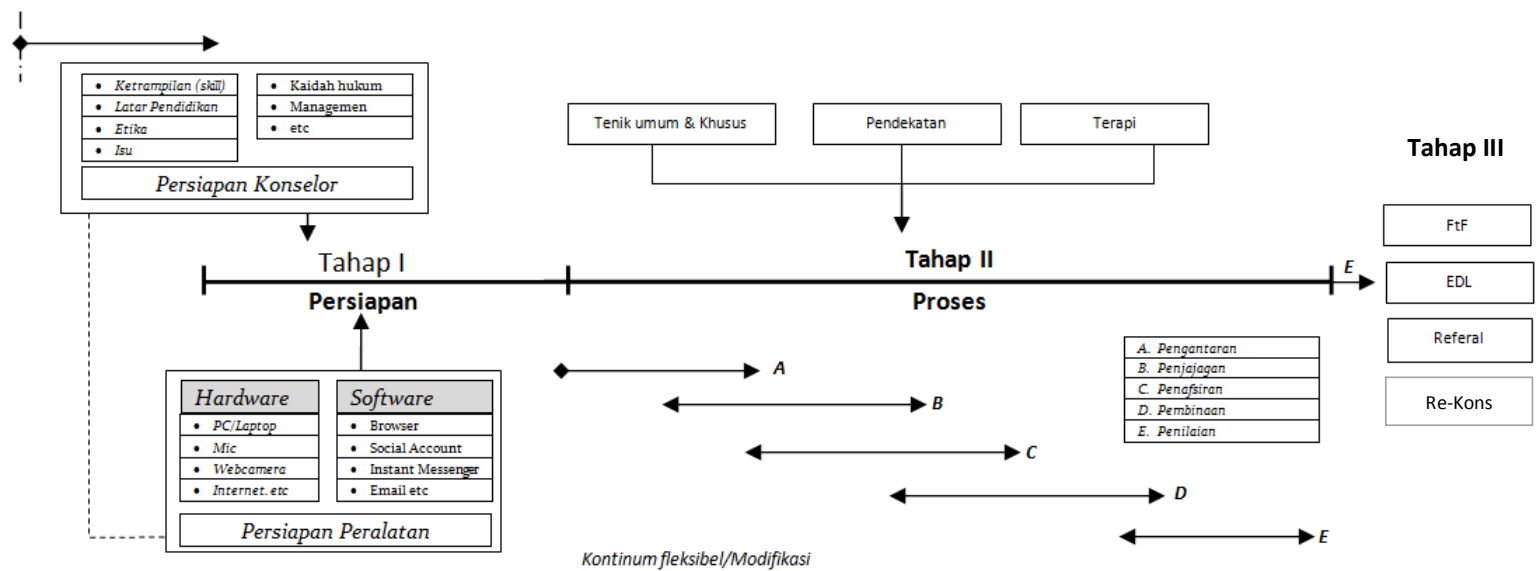

Gambar 1. Tahapan Proses Penyelenggaraan Konseling Online (Ifdil. 2011)

\section{Tahap I (Persiapan)}

Tahap persiapan mencakup aspek teknis penggunaan perangkat keras (hardware) dan perangkat lunak (software), yang mendukung penyelenggaraan konseling online. Seperti perangkat komputer/laptop yang dapat terkoneksi dengan internet/Ethernet, headset, mic, webcam dan sebagainya. Perangkat lunak yaitu program-program yang mendukung dan akan digunakan, account dan alamat email. Selain itu juga kesiapan Konselor dalam hal ketrampilan, kelayakan akademik, penilaian secara etik dan hukum, kesusuaian isu yang akan dibahas, serta tata kelola.

\section{Tahap II ( Proses Konseling)}

Tahapan konseling online tidak jauh berbeda dengan tahapan proses konseling face-to-face (FtF) tahapan (Prayitno. 2004) yaitu terdiri atas lima tahap yakni tahap, pengantaran, penjajagan, penafsiran, pembinaan dan penilaian namun dalam pelaksanaannya "kontinum fleksibel" dimana saling berhubungan dan bersambung sesuai tahap dan lebih terbuka untuk dimodifikasi, mulai dari tahap awal sampai tahap akhir, juga penggunaan teknik-teknik umum dan khusus tidak secara penuh seperti penyelenggaraan konseling secara langsung. Pada sesi konseling oneline lebih menekankan pada terentasnya masalah klien dibandingkan dengan cara bentuk pendekatan, teknik dan atau terapi yang digunakan. Pada tahapan ini pemilihan teknik, pendekatan dan ataupun terapi akan disesuaikan dengan masalah yang dihadapi oleh klien.

3. Tahap III ( Pasca Konseling)

Tahap tiga yaitu tahap pasca proses konseling online. Pada tahap ini merupakan lanjutan dari tahapan sebelumnya dimana setelah dilakukan penilaian maka yang pertama (1) konseling akan sukses dengan ditandai dengan kondisi klien yang KES (effective daily living- EDL) (2) Konseling akan dilanjutkan ada sesi tatap muka (Face to Face- FtF) (3) Konseling akan dilanjutkan pada sesi konseling online berikutnya dan (4) klien akan direferal pada Konselor lain atau ahli lain. 


\section{MEDIA KONSELING ONLINE}

Guru BK/Konselor dapat bertemu dengan klien/konseli dengan menggunakan teknologi. Kondisi ini bertujuan untuk memudahkan konselor dalam membantu kliennya, memberikan kenyamanan kepada klien dalam bercerita dengan menggunakan aplikasi teknologi sebagai penghubung dirinya dengan konselor dengan tanpa harus tatap muka secara langsung. Ifdil (2011) menyebutkan beberapa media yang bias digunakan diantaranya:

\section{a) Website/situs}

Dalam menyelenggarakan konseling online guru bk/konselor dapat menyediakansebuah alamat situs. Situs ini menjadi alamat untuk melakukan praktik online. Sehingga klien/konseli yang ingin melakukan konseling online dapat berkunjung ke situs tersebut terlebih untuk selanjutnya melakukan konseling online.

Untuk dapat memiliki wesite konselor dapat berkerjasama dengan perusahaaan dan/atau para pakar bidang web developer. Konselor dapat memilih bentuk design web yang diinginkan mulai dari html, php dan website yang menggunakan CMS (Content management system). Penyediaan ini membutuhkan biaya yang cukup besar.

b) Telephonel Hand phone

Lebih sederhana konseling online dapat dilakukan dengan memanfaatkan telephone. Dimana konselor dan klien/konseli bisa daling tehubung dengan menggunakan perangkat ini. "Telephone-based individual counseling involves synchronous distanceinteraction between a counselor and a client using what is heard via audio to communicate”.( National Board for Certified Counselors.tt).

Telphone/handphone dapat digunakan untuk menghubungi konselor. konselor dapat mendengar dengan jelas apa yang diungkapkan kliennya melalui fasilitas telphone/handphone. Dengan fasilitas ini pula Konselor dengan segeranya dapat merespon apa yang dibicarakan oleh kliennya. Rosenfield and Smillie (dalam Mallen, 2011) menyebutkan bahwa dalam Studi kasus menunjukkan bahwa konseling dengan menggunakan telepon dapat berjalan efektif dalam membantu menangani individu dengan efek psikologis kanker

c) Email

Email merupakan singkatan dari Electronic Mail, yang berarti 'surat elektronik'.Email merupakan sistem yang memungkinkan pesan berbasis teks untuk dikirim dan diterima secara elektronik melalui beberapa komputer atau telepon seluler. Lebih spesifik lagi, email diartikan sebagai cara pengiriman data, file teks, foto digital, atau file-file audio dan video dari satu komputer ke komputer lainnya, dalam suatu jaringan komputer (intranet maupun internet). Ada banyak penyedia account email gratis seperti @yahoo, @gmail, @aim, @hotmail, @ mail, @ tekomnet, @ plasa dan masih banyak yang lainnya.

d) Chat, Instant Messaging dan Jejaring Sosial

Chat dapat diartikan sebagai obrolan, namun dalam dunia internet, istilah ini merujuk pada kegiatan komunikasi melalui sarana beberapa baris tulisan singkat yang diketikkan melalui keyboard. Sedangkan percakapan itu sendiri dikenal dengan istilah chatting.. Percakapan ini bisa dilakukan dengan saling berinteraktif melalui teks, maupun suara dan video. Berbagai aplikasi dapat digunakan untuk chatting ini, seperti skype, messenger, google talk, window livemessenger, mIRC, dan juga melalui jejaring sosial seperti facebook, twitter dan myspase yang didalamnya juga tersedia fasiltas chatting.

e) Video conferencing

Video conference, atau dalam bahasa Indonesia disebut video konferensi, atau pertemuan melalui video. Pertemuan ini dibantu oleh berbagai macam media jaringan seperti telepon ataupun media lainnya yang digunakan untuk transfer data video. Alat khusus video konferensi sangat mahal sehingga alternatif Konselor dan Klien dapat menggunakan fasilitas video konferensi yangterdapat pada beberapa aplikasi Instant Messagingyang didalamnyasudah menyediakan fasiltitas video call. 


\section{EFEKTIFITAS KONSELING ONLINE}

Selama perjalanan penulis dari tahun 2008 melakukan konseling online, hal ini cukup efektif jika permasalahan yang dihadapi membutuhkan segera untuk dientaskan sementara tidak ada kesempatan atau terkendala jarak untuk dapat melakukan $F t F$ maka konseling online menjadikan alternatif pengentasan masalah. Dan ketika konseling online dilakukan dengan media yang lengkap (menggunakan video call) dengan didukung tersedianya jaringan internet yang sangat cepat, hal ini hampir sama dengan melakukan konseling FtF.

Finn \& Barak (2010) melakukan penelitian terhadap 93 konselor online menunjukkan bahwa secara keseluruhan konselor online puas dengan praktek mereka dan mereka percaya bahwa pelaksaannya efektif. Lebih lanjut (Zamani, 2010), meneliti sebanyak 20 responden dipilih sebagai subyek dan data dikumpulkan dengan menggunakan kuesioner untuk mengetahui pemanfaatan e-konseling antara konselor. Hasil penelitian menunjukkan bahwa walaupun responden memandang positif konseling online, namun konselor sendiri mengaku lebih suka tatap muka konseling untuk memberikan jasa mereka kepada klien, meskipun demikian pPenelitian ini juga memberikan catatan bahwa kedepan akan semakin banyak orang akan terus mencari ke internet sebagai sumber daya untuk menangani masalah-masalah kesehatan mental mereka.

\section{KETERBATASAN KONSELING ONLINE}

Keterbatasan konseling online diantaranya adalah konseling sangat tergantung dengan dukungan media, jika media yang digunakan tidak bermasalah, konseling akan lancar untuk dilakukan. Namun sebaliknya konseling online bisa saja terputus dan bahkan tidak dapat terselenggara dengan matinya listrik, koneksi terganggu, atau rusaknya perangkat yang digunakan. Kondisi lain adalah masih rendahnya atau tidak terlatihnya guru BK/konselor dalam penggunaan media. Tidak adanya pelatihan formal dan khusus yang dapat diikuti untuk terampil dalam penyelenggaraan konseling online. Konseling Online sampai saat ini di Indonesia tampaknya menjadiparuh waktu, dan sedikit tumpang tindihdengan praktek FtF. Lebih lanjut (Zamani, 2009). e-konseling / konseling online tidak akan menggantikan konseling konvensional. Meskipun disebutkan bahwa penyelenggaraan layanan konseling online, bisa menjadi komponen pentinguntuk meningkatkanprofesikonseling.

\section{PENUTUP}

Kedepan penyelenggaraan konseling online sangat membantu dan memungkinkan untuk dikembangkan dalam dunia bimbingan dan konseling khususnya di Indonesia. Meskipun sekarang secara khusus di Indonesia belum ada etik yang mengatur namun keberadaan media ini dapat mendukung penyelenggaraan bimbingan dan konseling secara luas untuk meningkatkan kompetensi dan efesiensi pelayanan demi terentasnya permasalahan yang dihadapi oleh klien/konseli.

Semoga kedepan para guru bk/konselor akan semakin melek teknologi, mampu menggunakan dan memanfaatkan teknologi informasi dan komunikasi. Dan tersedianya lembaga formal yang akan melatih ketrampilan tersebut. Dan juga LPTK secara khusus dapat memasukkan dalam kurikulum khusus berkenaan dengan Teknologi Informasi dan Komunikasi dalam BK. Dan juga semoga ke depan akan berdirinya lembaga khusus konseling yang menangani masalah khusus konseling online dan Pelayanan e-konseling secara umum.

\section{DAFTAR PUSTAKA}

Amani, Nasanin (2007).: Investigating The Nature, The Prevalence, And Effectiveness OfOnline Counseling, A Thesis, Department of Educational Psychology,Administration and Counseling, California State university Long Beach.

Businessdictionary.(2011). http://www.businessdictionary.com/definition/online.html

Capill, Lauren, (tt) Telecounselling and E-Counselling. Toronto : TAPE: TorontoAdvances Profesional 


\section{Education}

Csiernik, R., Furze, P., Dromgole, L., \& Rishchynski, G. M. (2006). Information technology and social work The dark side or light side? Journal of Evidence-Based Social Work, 3(3-4), 9-25.

Fields, Kenneth.(2011). About Online Counseling.www.openmmindcounseling.com.

Finn, J., \& Barak, A. (2010). A descriptive study of e-counsellor attitudes, ethics, and practice. Counselling and Psychotherapy Research, 10(4), 268-277.

Gibson, R.L. \& Mitchell, M.H. 2008. Introduction to Counseling and Guidance. New York: Macmillan Publisher.

Haberstroh, S (2009): Strategies and Resources for Conducting Online Counseling, Journal of Professional Counseling: Practice, Theory, And Research Vol. 37, No.2, Fall/Winter 2009

Haberstroh, S., \& Duffey, T. (2011). Face-to-face supervision of online counselors:Supervisor perspectives. Retrieved fromhttp://counselingoutfitters.com/vistas/vistas11/ Article_66.pdf

Ifdil. (2009). Pelayanan e-Konseling (Pengolahan Hasil Pengadministrasian Alat Ungkap Masalah (AUM) dengan Menggunakan Program Aplikasi). Paper presented at the Seminar Internasional Bimbingan dan Konseling Dalam rangka Kongres XI dan Konvensi Nasional XVI ABKIN

Ifdil. (2011). Penyelenggaraan Layanan Konseling Online Sebagai Salah Satu Bentuk Pelayanan E-Konseling dalam Syamsu Yusuf LN (2011) Contemporary and Creative Caunseling Techniques: How to Improve Your Counseling Skill and to be More Creative ini Counseling Sesion. Bandung: Rizqi Press

Koutsonika, Helen (2009) E-Counseling: the new modality. Online Career Counseling - achallenging opportunity for greek tertiary education. In: Proceedings of theWebSci'09: Society On-Line, 18-20 March 2009, Athens, Greece. (In Press)

Mallen, Michael J. David L. Vogel, dkk. (2011). Online Counseling, Reviewing the LiteratureFrom a Counseling Psychology Framework:, The Counseling Psychologist, Vol. 33 No. 6, November 2005. Houston: the Society of Counseling Psychology

National Board for Certified Counselors, Inc. and Center for Credentialing and Education, Inc., (tt) The Practice of Internet Counseling

Prayitno dan Erman Amti. (2004). Dasar-Dasar Bimbingan Dan Konseling. Jakarta. Edisi revisi Rineka Cipta

Prayitno. (2004). Konseling Pancawaskita. Padang: FIP

Prayitno. (2004a). Seri Layanan Konseling. L.5 (Layanan Konseling Perorangan). Padang: FIP. Jurusan BK. UNP

Russell K. Elleven and Jeff Allen.2011. Applying technologi to online counseling: suggestion for teh beginning e- therafist.http://www.sageperformance.com/drjeffallen/DrA/Downloading/Articles/OnlineCounseling.pdf

Winkel, W.S,.(2005). Bimbingan dan Konseling di Intitusi Pendidikan, Edisi Revisi. Jakart a: Gramedia

Zamani, Z. A. (2009). Computer technology and counseling. Paper presented at the International Conference on Computer Science and Information Technology, ICCSIT 2009.

Zamani, Z. A., Nasir, R., \& Yusooff, F. (2010). Perceptions towards online counseling among counselors in Malaysia. Procedia Social and Behavioral Sciences 5, 585-589.

Zeng, W., Yi, C., Chen, H., \& Xin, R. (2010). Web peer counseling system. Paper presented at the International Conference on Educational and Information Technology. 